\title{
«Air, sun, water»: Ideology and activities of OZE (Society for the preservation of the health of the Jewish population) during the interwar period
}

\section{Nadav Davidovitch(*) and Rakefet Zalashik (**)}

$\left.{ }^{*}\right)$ Department of Health Systems Management. Division of Public Health. Faculty of Health Sciences. Ben Gurion University. Israel. nadavd@bgu.ac.il

$\left(^{* *}\right)$ Skirball Department of Hebrew and Judic Studies. New York University. rz@nyu.edu

Dynamis

[0211-9536] 2008; 28: 127-149
Fecha de recepción: 10 de octubre de 2007

Fecha de aceptación: 14 de marzo de 2008

SUMMARY: 1.-Introduction. 2.-Jews and health in Eastern Europe. 3.-The establishment of OZE and its activities. 4.-OZE crisis and reconstruction. 5.-Typhus. 6.-Favus. 7.-Discussion.

ABSTRACT: This paper follows the social and political history of OZE, the Society for the Preservation of the Health of the Jewish Population, in the interwar period. We focus on two campaigns against typhus and favus, the first two disease oriented efforts by OZE, in order to reconstruct the operational approaches, considerations and obstacles faced by OZE as a Jewish organization and transnational participant in the discourse on the health and politics of minorities between two world wars. The analysis of OZE as a transnational Jewish relief organization has a wider significance as an example of international organizations originating from civil initiatives to promote the health of minorities through field work and politics.

PALABRAS CLAVE: Salud de entreguerras, organización benéfica judía, salud pública transnacional, tifus, tiña.

KEYWORDS: Interwar health, Jewish relief organization, transnational public health, typhus, ringworm. 


\section{Introduction}

OZE (Obshchestvo Zdravookhraneniia Evreev), the Society for the Preservation of the Health of the Jewish Population, was established in October 28, 1912 in St. Petersburg by Jewish physicians and prominent members of the community ${ }^{1}$. Its goal was to address the health problems of Jews in Russia and Eastern Europe - many of whom suffered from poverty and poor hygienic conditions as a result of deprivation and persecution that endangered the future of Jewish life of the area ${ }^{2}$. In 1919 OZE went through a serious crisis. It was closed down by the Soviets and reopened its offices in March 1922 in Berlin ${ }^{3}$. These offices became soon after the head-quarter of the organization.

This paper aims to follow the social and political history of OZE in the interwar period. We focus on the period from 1918 to 1926 when OZE's goals and modes of operation were consolidated. In this period, OZE successfully enlarged its activities, interacting with both the local context, Jewish and non-Jewish, and with organizations from Europe and the United States ${ }^{4}$. These activities tried to address questions of racial and contagious diseases, hygiene and prevention through public health campaigns and education targeting Jewish refugees, cities and villages inhabitants, orphaned children as well as mother and child health care.

1. Epstein, Lisa. Caring for the soul's home: The Jews of Russia and health care 1860-1914. Dissertation: Yale University; 1995, p. 255; Virginie, Michel. L'action médico-sociale de l'OSE à Paris dans les années trente. Archives Juives. 2006; 39 (1): 111.

2. OZE was not the only organization that was established to solve the problem of Eastern European Jews. Another important organization was ORT that aimed to turn Jews to productive individuals that would improve their economic state and their immigration chances. See for example: Ivanov, Alexander. From charity to productive labour: The World ORT Union and Jewish agriculture colonization in the Soviet Union 1923-38. East European Jewish Affairs, 2007; 37: 1-28.

3. The reasons for closing down the organization in Russia were partly due to problems with the Soviet regime and partly because of disagreements with the leadership of Jewish local communities (Kehila) that gained autonomy under Soviet rule. See: Shtif, N. Di zen jerike geschichte von «OZE», [The ten years history of OZE]. Volksgezunt, 1923: 2-3.

4. See for example the cooperation between OZE and EPOKO in Vilna during WWI: The Jewish District Committee of Wilno for Assisting the Victims of War, p. 7, AR 19/21 \# 227 Localities Poland-Vilna, Joint Archives NY. Cooperation between OZE, ORT and Emigdirect: Der Aufbau des osteuropaeischen Judentum, Hrsg. vom gemeinschaftlichen Hilfskomitee der zentralen juedischen Organisationen, ORT/OSE/Emigdirect, 1927[?]. 
Yet this paper follows not just an «internal» Jewish case study. The analysis of OZE as a transnational Jewish relief organization bears wider significances, as an example of international organizations originating from civil initiatives trying to promote minorities' health through field work and politics. In the first half of the 20th century health became a central concern and played a significant role in the formation and re-conceptualization of nations. It served not only to integrate and exclude peoples and groups, define borders and forge identities but also played a crucial role in the development of the political and social order. As the historians Iris Borowy and Wolf D. Gruner wrote: «The history of health in interwar Europe is in many ways the history of interwar Europe» ${ }^{5}$. With the rise of the welfare state, governments became involved in social policy supporting the creation of hygiene, education and consultation institutes. In addition, there was a shift from charity to broader strategies promoting welfare related to the developing scientific understanding of factors affecting health ${ }^{6}$. In the post World War I era, health became a potential focus to rebuild communities and nations. The changing political context of the interwar era brought the issue of minority health rights to the fore as well as the important role of international relief organizations that were operating in various countries in Europe. One of these ethnic minorities was the Jewish communities in Eastern Europe.

Our discussion focuses on two campaigns against typhus and favus, the first two disease oriented efforts by OZE to improve Eastern European Jews health conditions. Typhus and favus were two different public health threats that were considered «Jewish diseases» by both Jews and gentile physicians ${ }^{7}$. These diseases got special attention and relatively vast resources were allocated from Jewish relief organizations after World War I for their treatment. The examination of the campaigns against typhus and

5. See: Borowy, Iris; Gruner, Wolf D. eds. Facing illness in troubled times: Health in Europe in the Interwar years, 1918-1939. Frankfurt am Main: Peter Lang; 2005. Citation from the Introduction, p. 1.

6. Weindling, Paul. Philanthropy and world health: The Rockefeller Foundation and the League of Nations Health Organization. Minerva. 1997; 35 (3): 269-281.

7. On the racialization of typhus as Judenfieber see: Weindling, Paul. Epidemics and genocide in Eastern Europe: 1890-1945. Oxford: Oxford University Press; 2000. Another racialized Jewish infectious disease was trachoma, see: Markel, Howard. «The eyes have it»: Trachoma, the perception of disease, the United States Public Health Service, and the American Jewish immigration experience, 1897-1924. Bulletin of the History of Medicine. 2000; 74: 525-560. 
favus during the 1920s offers an opportunity to reconstruct the ways of operation, consideration and obstacle OZE faced, as both a Jewish organization and as a transnational participant in the discourse on health and its politics between two world wars. OZE medical policy and organizational work was part of broader transnational movement of ideas (scientific or managerial), people (health workers and relief administrators as well as refugees) and activities between «West» and «East». The research is based on published documents both in medical and lay publications, as well as on archival materials from the Center for Jewish History, New York and the American Joint Distribution Committee Archives.

\section{Jews and health in Eastern Europe}

The second half of the 19th century marked unprecedented social change transformed the face of Eastern European Jewry. Jewish persecutions and economic difficulties provided the impetus for mass emigration and the blossoming of new political movements, ranging from the secular socialist Bund (General Jewish Labor Union) to Zionism as well as the strengthening of competing religious ideologies ${ }^{8}$. This process happened during a period of vigorous debate on the «Jewish question». The «Jewish question» was the term that described the problem derived from the existence of Jewish minority within Christian society. The presence of a Jewish minority within ethnical collectives became more acute during the process of nation building that included the establishment of clearer physical and social borders and the determination of who belonged to the nation and who did not. Whereas the "Jewish problem» could be solved by conversion until the modern times, at the end of the 19th century, Jews were seen also as a distinctive race that could not be integrated into the nation.

One of the important areas where these changes and conflicts had a major influence was the medical and health realm. From the mid of the 19th century physicians became involved in the marginalization process of Jews, validating «scientifically» their «otherness». Whereas, in former times it was claimed that Jews tended to suffer from certain disease because of their

8. See for example: Orbach, Alexander. Russian Jewish History. Modern Judaism. 1990; 10: 325342; Nathans, Benjamin. Beyond the pale: The Jewish encounter with late imperial Russia. Berkeley: University of California Press; 2002. 
sins against Christianity and their belief, now the main prism was racial. It was claimed that Jews in general suffer from various pathologies as a result of their racial attributes. In particular, it was believed that the Jewish race is undergoing a process of degeneration. Weak nerves, late marriage and low fertility rates were used as an evidence for that ${ }^{9}$.

Most of the Jewish physicians accepted the claim about the degenerated state of the Jews. They explained it by the harsh historical past and the present living conditions of the Jewish people. The life in the Diaspora, the eternal wandering, the constant change of place of staying, the inquisition, the middle-ages Ghettos, the closed life in the cities far away from nature, the limitations on the field of economy and the social and political rights, all these - as claimed by both Jewish and non Jewish physicians - left traces on the Jewish body and mind, expressed in a weak "Jewish" physical constitution and fragile nerves system ${ }^{10}$. This state of a physical and mental degeneration of the Jewish people was seen as a national-social problem.

The need for a Jewish science, and particularly a Jewish science of medicine dedicated to the study of specifically Jewish health issues, became acute according to contemporary physicians and Jewish thinkers from the whole political spectrum. They strove to trace the reasons for the Jewish diseases and to offer a cure. The main subject for these improvements and reforms were Eastern European Jews. The actual condition of the Jews mainly in Tsarist Russia but also in other parts of Eastern Europe became a cause for concern for Western European and American Jewish communities. In contrast to their brothers in France, Germany and England who enjoyed equal rights as citizens and underwent assimilation into the gentile society, East-European Jews continued to suffer from severe conditions. These ideas of reform and philanthropy were loaded with ambivalent feelings: the idea of the East European Jew as dirty, foul-smelling, and disease carrying - the image of the Jew within the modern anti-Semitic discourse- was prevalent in both East and Western Europe ${ }^{11}$.

9. Hart, Mitchell. Social science and the politics of modern Jewish identity. Palo Alto: Stanford University Press; 2000.

10. Efron, John. Jewish doctors and race science in fin-de-siècle Europe. New Haven: Yale University Press; 1994.

11. Ascheim, Steven. Brothers and strangers: The East European Jew in German and German Jewish consciousness, 1800-1923. Madison: University of Wisconsin Press; 1982. 
The desire to remold the attitudes and practices of the Jews regarding hygiene was motivated by both altruistic and self-serving goals, to improve the health of the Jews but also to improve their image and status within modern society, in order to render them worthy of acceptance as equals in the eyes of other peoples. Despite of different contrasting models of Jewish identity existed at the time: class struggle (Bund), Religious, Acculturation (Liberals), Zionism, for all of them the promotion of Jewish health, coined in political terms, was important ${ }^{12}$. Health was becoming an important leverage for promoting Jewish political rights as a minority but also for its potential development as a nation.

According to the census from 1897, more than five million Jews lived within the boundaries of Tzarist Russia constituting slightly less than $4 \%$ of the entire population. Due to residency limitations, $90 \%$ of them were concentrated in the Pale of Settlement constituting $11.6 \%$ of the area ${ }^{13}$. The Pale of Settlement was created at the end of the 18th century following the division of Poland and was widened and altered at the beginning of the 19th; its final form was set in 1835 .

By the late nineteenth century about $80 \%$ of the Jews in the Pale of Settlement were concentrated in cities. Due to a rapid demographic growth, industrialization and capitalism, at this period we witness the «silent revolution» of East European Jewry. Life in East-Europe due to extreme poverty, the irrelevance of traditional Jewish occupations and anti-Semitism, became unbearable for many Jews who seek their fortune in other destinations. From 1870 big waves of Jewish immigration from East Europe to West Europe and to the new continent - especially to the United States- mark the decrease of East-European Jewry ${ }^{14}$.

\section{The establishment of OZE and its activities}

This background made the situation ripe for the establishment of OZE - the Society for the preservation of Jewish health. Its aims were to investigate scientifically the physical and psychic state of the Jews; to enlighten the

12. Hart, n. 9 .

13. Nathans, n. 8.

14. Alroey, Gur. Immigrants: Jewish immigration to Palestine in the early twentieth century. Jerusalem: Yad Ben Zvi Press; 2004, p. 12-13 (in Hebrew). 
Jewish population in hygienic matters; to help develop the state of local Jewish organizations and to encourage the Jewish population itself to conduct steps for the promotion of the physical and mental health of the Jews. OZE activities developed in a fast pace. Already in the first two years of existence it managed to open playgrounds for children ${ }^{15}$, children homes and training in public health for physicians and pedagogues, to propagate hygienic programs within the Jewish population, to conduct laboratory examination, to establish connection with medical Jewish institutions and the local governments in order to assure its legal and formal existence.

In the first years, OZE financed its activity from members' fees, donations and lectures. In January 1914, for example, it had a capital of 4,500 Rubles ${ }^{16}$. In 1916 its budget was already 360,000 Rubles but the expenses were 1,332,000 Rubles. In 1917 there was a change in the financial strategy of OZE. While until then the central committee was responsible for allocating the money for the organization's activity, from 1917 onwards, OZE demanded that some of the money would be allocated by the local communities ${ }^{17}$.

In 1917 OZE was active in 107 towns and cities including 40 playground for 15,000 children, 27 children homes for more than 8,000 children, 15 summer camps for 2,000 children, 5 children kitchen that distributed 3,000 lunches per day, 50 dining points for 24,000 school children, 60 ambulatory stations and 6 hospitals with 230 beds. It employed 600 medical and pedagogue personnel. In addition it published public health literature, a medical journal and brochures ${ }^{18}$. While this was a rapid growth, because of the dire conditions of Jews and non-Jews at the end of the war OZE activities could not meet the needs of the various Jewish communities ${ }^{19}$.

The activity of Jewish physicians among the Jewish population was not new. However, whereas until the foundation of OZE these Jewish medical

15. The idea of playgrounds for children and the attention given to their plays as part of their development was a totally new concept within Jewish communities. In 1914, OZE published the first book in Yiddish on children's playing.

16. Shtif, N. Di zen jerike geschichte von «OZE», [The ten years of history of OZE], Volksgezunt 9-10, Sep.-Aug. 1923: 3.

17. Shtif, n. 16.

18. Shitf, n. 16, p. 1.

19. Peker M. Di Soziale un Guzuntheits ferhelnisen nakh der Milkhume [The social and health situation after the war]. Folksgezund, March 1923, 1-4; Kotik, Avraham. Di welt milkham un Poilen [The World War and Poland], Volksgezung 2-3, 1923: 6-8. 
frameworks were aimed to aid the poor and sick, mainly as a «first-aid» facility, OZE activity was essentially different. It strove not to replace or strengthen the traditional medical frameworks, for it argued that these organizations bring no real change in the state of Jews. Instead, it wished to establish its activities within a new social preventive new medicine framework. Moreover, since it believed that the source of some of the typical «Jewish diseases» was the people's ignorance and bad hygienic practices, curing without educating seemed as a Sisyphean activity doomed to fail. Nevertheless, the existing Jewish welfare-medical organizations created previously to the establishment of OZE, were used by it and enabled its relative quick start and rapid development.

As a practical matter, Jewish physicians were encouraged to focus on treating Jews, to establish special clinics and hospitals and to carry out public health campaigns. But perhaps more significantly, OZE was engaged in medical politics within both the general society and the Jewish community. Their goal was to establish a Jewish social-medical organization on the model of Russian zemstvo system of social medicine ${ }^{20}$. The zemstvo was a system of elected district councils with extensive responsibilities for health, education and economic infrastructure ${ }^{21}$. According to the zemstvo model regarding health care, OZE has two main ends: sanitary medical action by education, research, propaganda as part of a medical organ and the preoccupation with the young generation in order to revive the Jewish people, to fight diseases, weakness and degeneration ${ }^{22}$. Local governments were interested in collaborating with OZE to reduce their responsibility for the Jewish population and to improve the general sanitary infrastructure. The Russian government began to support OZE's activities from 1915. At that year 11\% of OZE's budget came from the Tzarist regime. In 1916 it increased to $55 \%{ }^{23}$.

20. Epstein, n. 1, p. 253; Emmons, Terence; Vucinich, Wayne S., eds. The Zemstvo in Russia: An experiment in local self-government. Cambridge/New York: Cambridge University Press, 1982; Porter, T. E. The Zemstvo and the emergence of civil society in late imperial Russia, 1864-1917. San Francisco: Mellen Research University Press; 1991.

21. Zemstwo system was not applied in the areas of the Pale, where most of the Russian Jews were living.

22. Shtif, N. Di zen jerike geschichte von «OZE», [The ten years history of OZE], Volksgezunt 1, 1923: 1

23. Shtif, n. 22, p. 3. 
As part of its early effort, OZE activists wanted to provide the Jews with a national history in the sphere of medicine and public health, just as historians such as Zvi Graetz and Simon Dubnow had begun constructing a history of the Jews in socio-economic and political spheres ${ }^{24}$. Thus, OZE aimed to develop a historical perspective that combined the physical evolution of the Jews, Jewish medicine, hygiene and sanitation. Not surprisingly, similar to other health movements of the time, where national and public health goals were intertwined, OZE had its own eugenic component ${ }^{25}$. In Poland, enthusiasts of Jewish eugenics came together to form the Section for Social Hygiene and Eugenics (Sekcja Higieny Spolecznej i Eugeniki) as part of the local branch of OZE established in $1918^{26}$ (later to become TOZ in 1922), and in general eugenics, broadly conceived and interpreted served as the scientific background for OZE public health activities. As in other movements, the concept of hygiene and the concept of eugenics were interwoven.

During World War I, OZE accelerated its activities. Moreover, it seems that war was an opportunity for OZE to expand and become a crucial agent both in a local and national level. One can assume that if the war would not take place, the organization would have not survived. Already in autumn 1914 it sent a rescue team that opened kitchens, hospitals, children home and disinfection means to secure the physical existence of the refugees. During the first months of war the old Jewish relief organizations collapsed and the Russian regime lacked any mechanism to help the civil population. The war brought great deprivation and suffering to all communities, Jewish and non-Jewish, in Eastern Europe. The main victims were the ones in Russia, Poland and the Ukraine. In addition to those who fled due to war, some were raped and expelled ${ }^{27}$. According to one estimate, by the beginning of 1917 the size of the overall refugee population in Russia exceeded 6 million,

\footnotetext{
24. Epstein, n. 1, p. 258.

25. Uzarczyk, Kamila. «Moses als Eugeniker»? The reception of eugenic ideas in Jewish medical circles in interwar Poland. In Turda, Marius; Weindling, Paul, eds. Blood and the homeland: Eugenics and racial nationalism in Central and Southeast Europe, 1900-1940. Budapest: CEU Press 2007; p. 283-298.

26. Uzarczyk, n. 25, p. 289-290.

27. Kotik, n. 19, p. 8. In the winter of 1914/1915 OZE established a refugee camp for 109,000 Jews.
} 
accounting about $5 \%$ of the whole population ${ }^{28}$. Hundred thousands of Jews became refugees, wandering in the roads without enough food-supply or medical treatment. Persecutions, famine and epidemics became part of everyday life. The schools and synagogues the refugees found shelter due to epidemics such as typhus, scarlet fever, small pox and cholera, turned into graveyards ${ }^{29}$. The army assumed governance over most of the western districts of the Russian Empire and public organizations which centered on the Union of Zemstvos and the Union of Towns dealt with the needed social services, collaborating with the army. Tensions existed mainly around the question of refugees, as many were deported by the army on the ground of loyalty suspicion in war zones (many of them Jews). Local relief for Jews, Poles and Ottoman Armenians refugees was organized by "settled" residents of the same ethnicity. In this process new social identities were formed, helping to crystallize ethno-national identities, the Jewish being one among others ${ }^{30}$.

OZE enjoyed the same privileges of the general Red Cross and received supplies from the Russian army to help the refugees. In the help centers it established in various location it had laboratories, schools, kindergartens and training schools activated by ORT. The urgency of OZE's activities during World War I led to its expansion and it gained sympathy. From a small group of 45 employees it became at the end of 1917 a relatively large organization with 600 permanent workers, 15,000 members and a headquarter in Moscow.

Nevertheless, alongside its activity to help war refugees, OZE had also developed in other fields. In 1916 it began to work in the preventive medicine field, first with mothers and their children. Although the infant mortality rate was relatively low among Jewish population due to lack of alcoholism and syphilis, it was believed that it can be decreased even further by opening consultation and milk-station where poor mothers could get milk and information about the new developments in the field of hygiene. The first OZE milk-station was opened in January 1916 in Minsk.

28. Gatrell, Peter. A whole empire walking: refugees in Russia during World War I. Bloomington: Indiana University Press; 1999, p. 3.

29. Whereas between 1910-1915 the mortality rate of Jews was 15-20 deaths per 1000 people, in 1915 it increased to 71. Shtif, n. 22, p. 2.

30. On this process of refugees and the construction of national identity, see Gatrell, n. 28, p. 141170. 
In 1917 OZE ran already 10 stations treating more than 2,500 infants ${ }^{31}$. The biggest problem, however, was with school children who were going to Heders (Elementary religious Hebrew school, usually held at the teacher's residence) where OZE had no control on. For this OZE made a campaign and in 1916-17 its physicians conducted a research on the state of children in the school age ${ }^{32} .62 \%$ children suffered from rickets (softening of bones), $10 \%$ had skin diseases, $15 \%$ were short-sight and $8 \%$ suffered from lung and heart diseases. For OZE the reasons for this bad state were the economic situation of the parents, bad hygiene, the studies in Heder and the lack of physical education ${ }^{33}$. The first project was opening kitchens in schools where breakfast and lunch were served. In addition, OZE carried out a sanitatary inspection, doctors visits who screened and treated the children and a campaign among the teachers about the importance of sanitary and hygienic rules.

\section{OZE crisis and reconstruction}

From the Russian revolution in 1917 but mainly in 1918 OZE experienced a deep crisis and the situation became critical for its existence. The immediate causes were the German occupation, the severe situation of the Jewish population and a conceptual crisis within OZE. Although the Russian Jews gained equal rights as citizens and were able to organize their communities based on democracy, OZE's activity was limited by the communities themselves ${ }^{34}$.

OZE did not operate in a vacuum. The main Jewish relief organization at that time was the American Joint Distribution Committee founded in 1914 to send aid to the Jews of Eastern Europe and Palestine who were in danger of starvation ${ }^{35}$. One of its main operating principles was to build

31. Shtif, N. Di zen jerike geschichte von «OZE», [The ten years history of OZE], Volksgezunt 2, March 1923: 1.

32. This research was the milestone of OZE's scientific knowledge regarding this group. The results were published in "Yediot».

33. Shtif, n. 31, p. 2

34. Shtif, n. 31, p. 3

35. On November 27, 1914 the Central Relief Committee established by American Orthodox Jews and the American Jewish Relief Committee established by prominent German-American Jews agreed to coordinate the distribution of relief shipments to Jews overseas within a 
strategic alliances with other organizations that would take over responsibility for what the JDC helped start. One such organization chosen by the JDC was OZE. During the interwar period, JDC financed about $25 \%$ of OZE activities. As with other projects supported by the JDC, this cooperation created a strong and important relationship but also tension between the American approach and the local intents.

It should be understood that OZE activities were not only important in the health realm. Immediately after the war, OZE organization together with other local initiatives channeled also the political self realization of the Jewish communities. Its medical help and housing for refugees; its network of consultation stations for children; milk kitchens; kindergartens; summer camps for children; ambulatory stations and hospitals; were also part of a political process to strengthen Jewish identity. At this stage also an organizational change took place. OZE opened local offices and recruited more Jewish physicians for its initiative on the local-district basis ${ }^{36}$.

After World War I, branches of OZE spread also to the newly established states of Poland, Lithuania, Latvia and Rumania, as well as other countries in Central and Eastern Europe. In 1922 a separate yet related organization in Poland united to form TOZ (Towarzystwo Ochrony Zdrowia, The Society for the Protection of Health) ${ }^{37}$.

In Poland, TOZ and OZE collaborated as separate organizations until 1926. After a short period of operating as a single organization (under the name OZE-TOZ), in 1927 TOZ took over the OZE institutions in Poland and Lithuania. TOZ remained closely associated with OZE headquarters in Western Europe. Its first president Gershon Lewin, exemplified the founders of OZE: born in Lublin in 1858, son of a cantor, he studied medicine in Warsaw. After practicing in the Polish-Russian area, fighting cholera epidemics, he was recruited as a military physician in the Russian-Japanese war in the Far East. After being released from the Russian army he settled in Warsaw and began to work in a Jewish hospital, to became the head of the tuberculosis department. As many other OZE activists Lewin

common framework - the Joint Distribution Committee of American Funds for the Relief of Jewish War Sufferers - under the chairmanship of Felix M. Warburg. The socialist People's Relief Committee joined them in 1915. The diversity of these three groups ensured that JDC would assist Jews of every religious and political persuasion.

36. Die Entstehung der Gesellschaft OSE und ihre ersten Massnahmen. Berlin: Verband fuer Gesundheitsschutz der Juden OSE, 1925, p. 4.

37. TOZ continued to run its multitude of programs until it was shut down in 1942. 
lived in two worlds - the medical world and the world of Jewish culture and activism ${ }^{38}$.

After the liquidation of OZE in Russia, two district offices remained in the Russian territory in Vilna and in Bialystok. At the end of 1921 another office was revived in Lithuania ${ }^{39}$. These offices kept their daily activity among the Jews and were important for the continuity of the organization in the area but actually were mainly keeping the awareness of the Jewish population to OZE existence.

In March 1922, the office of OZE was established in Berlin. Its purpose was to help the Jews in the Ukraine that were in a catastrophic situation; not yet recovered from the pogroms during 1918-1921, they experienced famine, epidemics and death. OZE Berlin promoted a campaign about the situation of the Ukraine Jews among the Jewish communities in Western Europe. They managed to collect a remarkable amount of money and after immense efforts they managed to become active again in October 1922 in Ukraine through the mediation of Nansen mission and the Jewish Help Conference ${ }^{40}$. From autumn 1922 they sent medicine to Ukraine and from February 1923 they began their medical activity. With the activity of OZE's representative in Russia, Dr. M. Gran, 80 institutes were established. In parallel to this activity, OZE Berlin opened branches in London ${ }^{41}$, Paris, Lettland, Danzig. In spring 1923 it expanded its activities to Rumania ${ }^{42}$.

OZE engaged in diverse socio-medical activities and became an important factor in Jewish public health, focusing primarily on children's health and welfare. It conducted broad educational campaigns to promote general hygiene and taught methods of preventing the spread of infectious diseases. The educational campaigns included lectures delivered in community centers and in schools, articles in Jewish journals and professional medical periodicals, books and a wide use of propaganda posters and

38. Wollman, L., ed. In the struggle for health of the Jewish people (50 years OZE), p. 298-299.

39. AR 21-23 \#235 Countires: Lithuania Subject Matter Medical 1921-1929. Joint Archivers, NY.

40. Inermeditzinish Sanitare tetikhkeit fon «OZE» in di Ukrain [The medical sanitary activity of OSE in the Ukraine], Buletin fon zentral Biro fon der geselschaft fur ferhiten di gezuntheit fon der idisher befolkerung «OZE», Berling, June 1923, n. 2, p. 2.

41. Di Grindung Fersamlung fon «OZE» in Landan [The founding meeting of OZE in London], Buletin fon zentral Biro fon der geselschaft fur ferhiten di gezuntheit fon der idisher befolkerung «OZE», Berling, June 1923, no. 2, p. 10.

42. Buletin fon zentral Biro fon der geselschaft fur ferhiten di gezuntheit fon der idisher befolkerung «OZE», Berling, June 1923, no. 2, p. 42. 
flyers. The range of lecture topics, from home cleaning to sex education, given by doctors even in remote villages, was unprecedented in scope. The series of posters, mostly in Yiddish, can be located at the YIVO archives and can serve as an invaluable resource for the analysis of contemporary understanding of health and diseases.

Two infectious diseases that were chosen initially as the focus of various relief organizations including OZE were typhus and favus. We analyze these two different stigmatized "Jewish" diseases in order to show the patterns and strategies of its activity and also the interaction between OZE and other organizations mentioned above.

\section{Typhus}

Typhus is a term given to several similar diseases caused by Rickettsiae bacteria. The epidemic or classic form is louse borne. Symptoms of epidemic typhus are high fever, chills, headache, exhaustion and skin rash. After recovery from the disease, character changes could persist including memory loss, lethargy and disorientation. The disease has been known along history and flourished under conditions of poverty, crowdedness such as those found in prisons, war and refugee camps. During War World I, typhus caused about three million deaths in Russia, as well as many more in Poland and Rumania. A network of delousing stations was established on the Western front in order to stop the advancement of the epidemic. Between 1918-1922 typhus caused more three million deaths out of 20-30 million cases, Eastern Europe being the main center of this outbreak.

As described by Paul Weindling the response to typhus derived from a broader hygienic paradigm. Quarantine of individuals or even whole communities and fumigation against foul airs had been routine already from the 17th century. Yet, since the 1890s hygienic work and propaganda took a novel turn when specific insects were assigned specific diseases and medical scientists developed a battery of preventing measures which included the use of chemicals and gases. The benign existence of men and lice turned into a sanitary war on parasites ${ }^{43}$. 


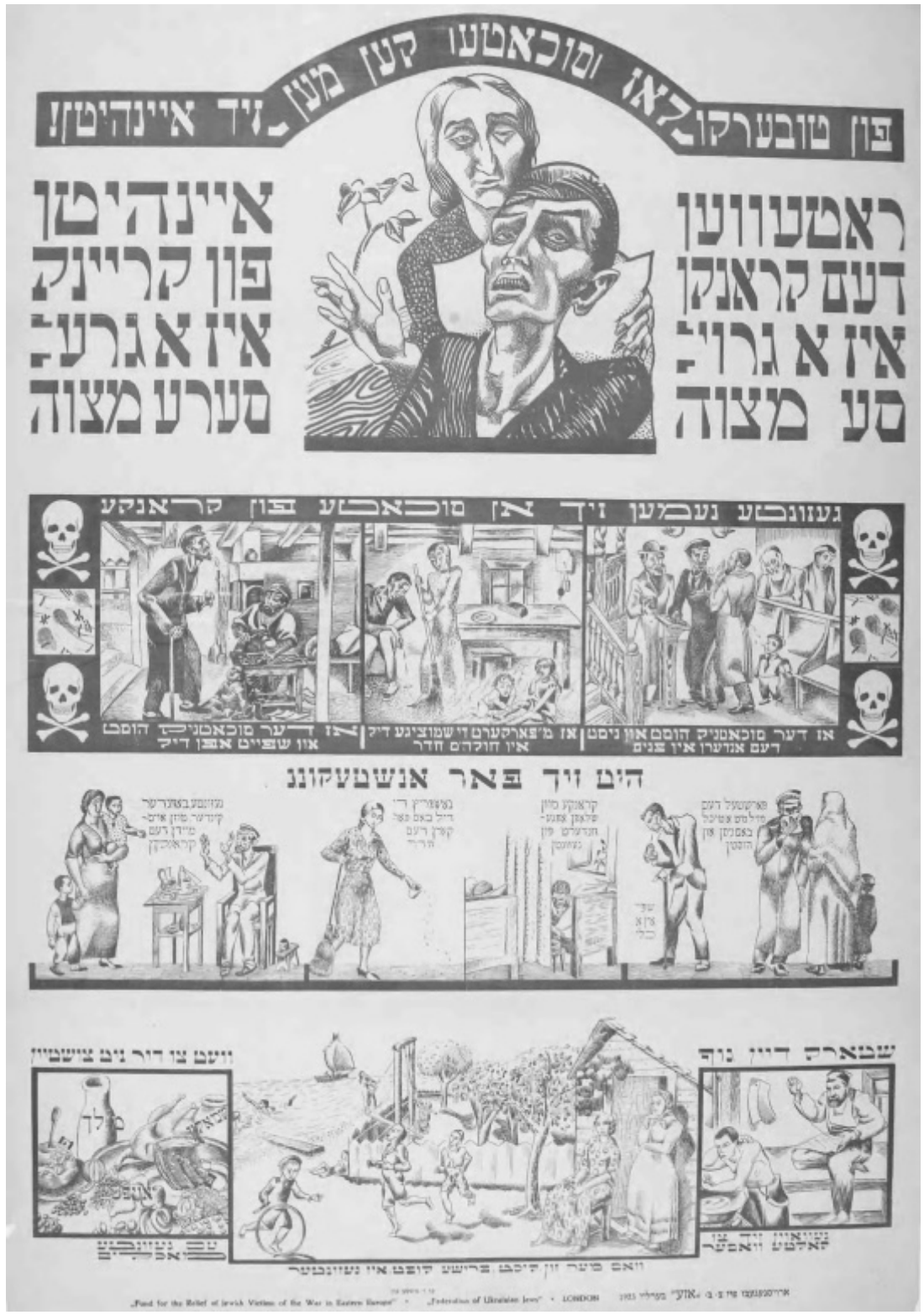

Figure 1. «Blood, Frogs, Lice - the third plague is the worst. Protect yourself from lice! You get typhus from lice. Here is a usage of the Ten Plagues foisted upon Egypt to convince Pharaoh to let the Israelite slaves go». This story is part of «Passover» holiday and is associated with catastrophes. From the Archives of the YIVO Institute for Jewish Research, New York. 


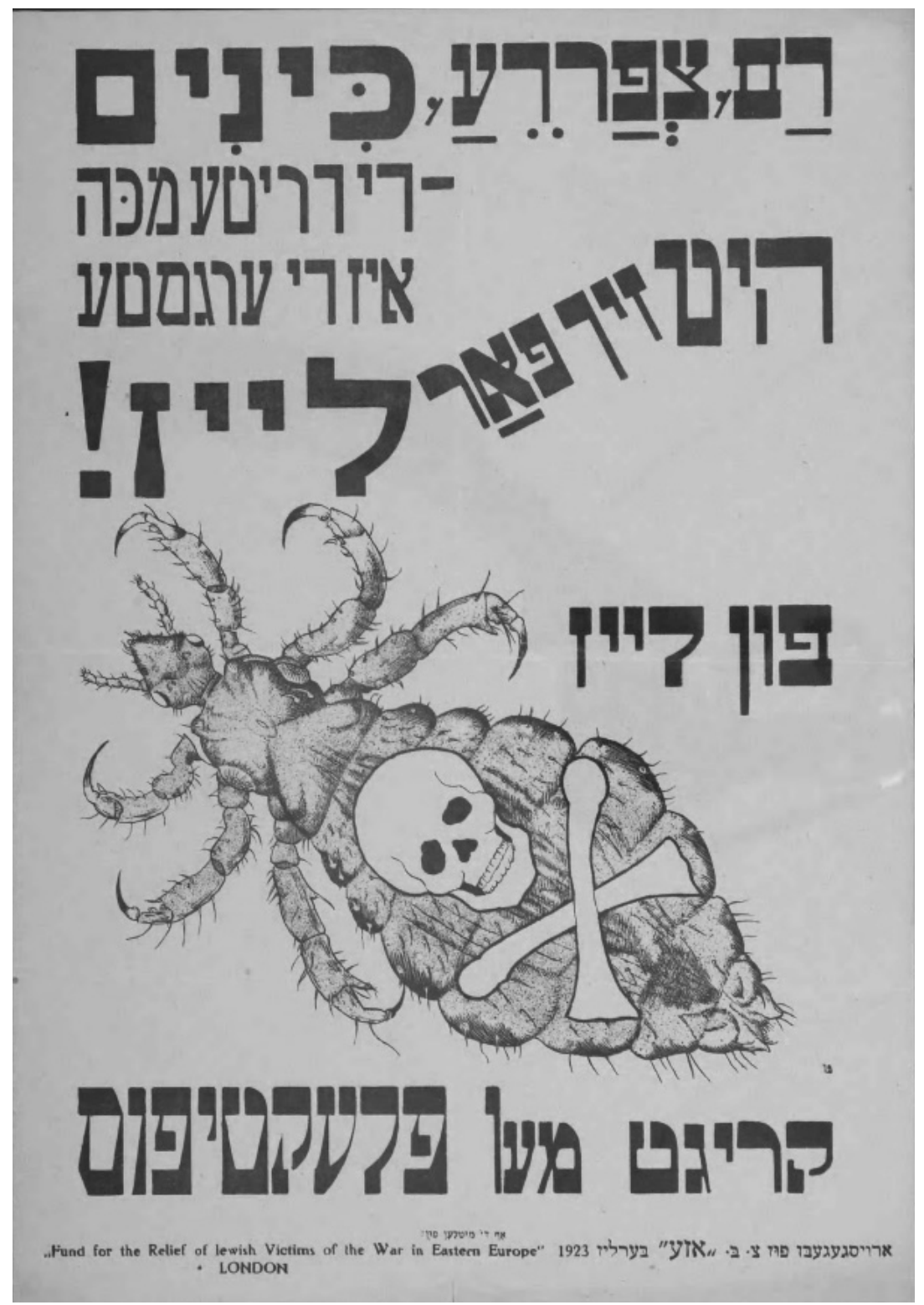

Figure 2. "You can protect yourself from tuberculosis. To save the sick is a big Mitzvah (Jewish commandment), to prevent the disease is an even bigger Miztvah». According to Judaism a Jew is obliged to do commandments and to specifically search for the opportunity. From the Archives of the YIVO Institute for Jewish Research, New York. 
Warnings about typhus epidemics in East-Europe as a result of war and the collapse of sanitary organizations arrived to Western European and American Jews. The JDC decided to focus its activities on typhus and to establish a special scientific commission to investigate the situation and possible remedies. Harry Plotz, then a young Jewish physician at the beginning of his career becoming later an infectious disease expert specializing in typhus, was assigned in March 1920 «to carry on scientific investigations and to propose such remedial measures as may deem fit and to assist all other agencies engaged in investigating and combating the typhus epidemic in Poland and in other countries in Europe» ${ }^{44}$. The initial task of the delegation was to survey the general health condition in Poland ${ }^{45}$. According to Plotz, before the war sanitary organizations were primitive however existing. The situation of Jewish population, all residing in refugee camps, after six years of destruction was catastrophic: most of the property was lost and many remained with no shelter. The severe housing problems, crowded conditions, hunger and unbearable hygienic situation led to high mortality rates especially for infants. Plotz recommended that the JDC should get deeply involved in anti-typhus campaigns among the Jewish community as many Jews suffered from the disease. The urgent need for action in the Jewish communities was strengthen by the anti-Semitic propaganda under the disguise of health campaign against typhus, leading to violent actions from beards violently shaved to actual pogroms.

Plotz reported that in every big city there was at least one Jewish hospital. However, some of them were confiscated by the government and functioned as military hospitals during the war. According to his plan 15 young energetic physicians should be sent from the US to organize the local medical framework. Plotz estimated the need for a 2 million dollars budget for one year for medical treatment and public health campaign in Poland. Following Plotz report and recommendation, a delegation of 18

\footnotetext{
44. A letter from Harry Plotz to Felix Warburg, October 1920, JDC Archives, NY.

45. This investigation was part of JDC broader efforts to conduct an epidemiological survey of Jewish health in Eastern Europe. In various cities data was gathered by distributing questionnaires to a sample of Jewish households together with the use of official vital statistics from the municipalities. See for example: William Wovschin, Report on medico-sanitary conditions in USSR, July 1920-March 1921, JDC Archives, NY. See also: Letter from Dr. Charles Spivak to Dr. Julius Goldman, JDC, Paris, September 1920. JDC Archives, NY.
} 
physicians was sent from the USA to Poland to conduct the medical and public health work.

Plotz tried to initiate a massive public health campaign in the Warsaw area with the collaboration of local Jewish physicians and prominent citizens. A meeting with the Polish health minister and the JDC took place in November 1920 where it was agreed that the JDC would start its activity in Poland against typhus fever. Although JDC planned a budget of $2 \mathrm{mi}-$ llion dollars for the first year, finally only half a million was collected. The delegation, sponsored mainly by the JDC, started its activities soon and distributed literature in Yiddish on typhus in cooperation with the Polish government, opened baths and gave soaps. In addition a movie was made that explained to the local population how typhus is transmitted and how it could be avoided. These activities opened the possibility for cooperation with local medical forces, OZE being an important option. The need for cooperating with local forces such as OZE was reinforced by the opinion of other JDC medical representatives who did not agree with Plotz recommendation of sending physicians from the US to Eastern Europe. William Wovschin, who conducted a survey of the medical and sanitary conditions in the USSR, thought that sending physicians from US to Russia is useless since they did not speak the local language and do not understand the culture. In addition Wovschin opposed the idea of sending supervisors from the US since Russian physicians were intelligent enough to organize the medical and public health work. In contrast, he considered the case of nurses as different. Since there was a lack of nurses, he offered to send nurses from the US that would train local Jewish girls to become nurses and serve the community ${ }^{46}$.

Although initially the Polish government cooperated, the activities organized by Plotz faced many obstacles as the local government retreated from their original support. In March 1921, following Plotz recommendation a group of American Jewish physicians were sent to Poland to observe the situation and collect data without giving any medical care. During this time, OZE as a local Jewish public health organization was mentioned in JDC documents as a possible solution to continue the medical and sanitary efforts, supported financially by the JDC. The turning point in the debate of

46. See Wovschin, n. 45. Indeed a few schools for nurses were established in the next years with American teachers. 
who should take responsibility on the medical and public health work was a conference of Jewish medical representatives. There were 47 representatives in this conference, most of them local and some from various relief organizations from abroad, mainly the JDC. Preceding the conference, a questionnaire was sent that reflected the debate regarding responsibilities and proper ways to continue the campaign.

In the opening speech at the Lemberg conference Plotz said:

«the relief work of the JDC is taking a new aspect; until now all the work and the responsibility have been so to speak monopolized by the JDC. Now the Polish Jewry is invited to participate in the work to share in the responsibility and to contribute financially» 47 .

Although Plotz left his position as head of the typhus committee by 1921, following his personal disappointment with AJDC, typhus activities continued. The Lemberg conference was headed by other conferences such as one in Warsaw in July 1921 and addition to «district conferences» where meetings with local activists in each district were organized. During these conferences the place of OZE as the central public health organization operating in Poland and other Eastern European countries was solidified. OZE centrality took place both on the local level, as an organization that knew the language, local culture of both Jewish and non Jewish organization, and also in the eyes of Jews across the ocean, mainly JDC, who could help with financial and managerial support. Typhus epidemics, the worst menace during and immediately after the war, served as a case study where these understandings were developed. JDC understood that they need to develop the local forces in order to execute their public health programs. OZE needed the time and experience learnt during the typhus campaigns to reinforce their status. The next disease they chose to cope with was another «Jewish disease» - favus and ringworm.

\section{Favus}

Favus, «honeycomb» in Latin, is a dermatological lesion caused by a fungus. It is usually a disease of the scalp, but can occur occasionally on any part of the skin. A related disease is ringworm another scalp disease caused by

47. AR 19/21 \#210 Localities Poland, Medical Sanitary. Joint Archives, NY. 
various Tinea species. The two affect mainly children and young adults. The diseases are known for centuries and have been usually related to other «loathsome» diseases such as trachoma, parasitic infections and venereal diseases. Despite that relatively benign course patients were highly stigmatize and in general these ailments were considered as related to poverty and backwardness. During the period of mass immigration at the turn of the 20th century, favus and ringworm had an important personal implication for future immigrants as they were part of a list of diseases that could not allow immigrants to enter countries such as the US and Canada ${ }^{48}$.

Favus and ringworm control was considered by contemporaries as an important public health problem. Jews in Eastern Europe suffered from high rates of favus and ringworm of the scalp. In Russia the estimation was that at least 25,000 Jewish children (not only orphans) were infected ${ }^{49}$. It was considered as a Jewish disease, termed parech in Poland. The high morbidity of the disease among Jews were explained by a bad hygiene, humid, dark and unventilated places, but also due to the Jews - as part of their observance- to wear hats ${ }^{50}$.

After the war Jewish organizations, both from the US such the JDC and local such as OZE, declared war on favus. OZE enacted anti-Favus committees to deal with the disease. In their reports JDC explained that the fight against favus can improve the status of Jews in Eastern Europe, decreasing the stigma related to the disease and allowing them to immigrate more easily to Western countries. The special commissioner for health and sanitation of the JDC, Dr. Charles Spivak, who toured Poland in 1920, wrote in his report that «the eradication of favus in Poland will be the greatest boon to mankind and will be of lasting credit to the J.D.C.» ${ }^{51}$.

The various JDC medical experts agreed that the only way to fight favus was the opening $\mathrm{x}$-ray stations for favus and ringworm irradiation. Accordingly, during the Lemberg conference held in June 1921, favus treatment was one of the major topics discussed. Already in May 1921, the JDC approved the purchase of $\mathrm{x}$-rays machines for Eastern Europe for

48. Markel, Howard. Quarantine! East European Jewish immigrants and the New York City epidemics of 1892. Baltimore: Johns Hopkins University Press; 1997.

49. Another report mentioned that $26 \%$ of Jewish Russian children suffered from Favus. Die Entstehung, n. 36, p. 7.

50. «Wegen oisraten di krankeit'parekh' bei iden» [on the liquidation of the disease «Parekh» among the Jews], Volksgezunt 2, March 1923: 1.

51. Confidential report from Dr. Spivak to Dr. Julius Goldman, 13.4.1920, p. 18. Joint Archives, NY. 
favus treatment. As the local organization OZE decided to took as one of its main tasks to eliminate the disease from the Jewish world and therefore it decided to open the favus centers. The first machines were ordered in May 1921 with the promise to arrive in September that year ${ }^{52}$. However, it was not until autumn 1922 that the first machine was put in Vilna and began to function in November $1922^{53}$. According to Dr. Michlin's survey from 1921, there were 17,500 cases of favus in Poland ${ }^{54}$.

However, the technical availability was not enough. OZE began a public campaign among all strata of Jewish population to inform about the disease, its consequences and the new methods to treat it. It asked the communities to contact the anti-Favus committees and to direct patients to the $\mathrm{x}$-rays stations for treatment ${ }^{55}$. From the end of 1921 a criticism was expressed against the idea of ambulatory treatment of favus. It was claimed that the treatment would take very long (between five and seven months) and in the meantime the treated patients would return home and infect their family members. Therefore, it was suggested to put $\mathrm{x}$-rays machines in Jewish medical centers, to isolate the favus patients and to treat them in a concentrated session of 5-7 weeks ${ }^{56}$.

The main problem was with patients from the provinces who did not have money to travel to the next big city and receive treatment. There was a twofold solution: OZE had mobile x-rays units and the centers located in the big cities had special dormitories for children who were coming from the province. OZE reports across Eastern Europe described the detailed

52. Report of Medical Commission Conference, Warsaw, 10.12.1921, p. 12-13, Joint Archive NY. Dr. Golub collection, Joint Archives, NY. Medico-Sanitary Department, Warsaw, 1921.

53. See n. 50.

54. 3,000 cases of favus in Warsaw, 2,000 in Congress Poland, 2,000 in Bialystok, 2,500 in Vilna, 2,500, 2,500 in Bowno, 1,500 in Krakow, 2,000 in Lemberg and 2,000 in Brest-Lotovsk. Report of Medical Commission Conference, Warsaw, 5.12.1921, p. 12-13, Joint Archive NY. Dr. Golub collection. Medico-Sanitary Department, Warsaw, 1921.

55. See, for example an announcement directed to «the Jewish population around Vilna, the heads of all Jewish organization, the communities, the help-commissions, the societies, the associations, the studying school, the circles, the Rabbis, the teachers, civic activists, the physicians, medical attendants and midwives». Volksgezunt 2, March, 1923.

56. Dr. H. Resnikow, Favus clinics, 22.11.1921, Joint Archive NY, Dr. Golub collection, Joint Archives, NY. Medico-Sanitary Department Warsaw 1921, p. 1. Interestingly, the AJDC appointed Ignaz Zollschan, at the end of 1921 as head of the roentgenology department. Zollschan, better known as a Jewish Austrian physician and anthropologists who worked on the "Jewish question», was also a radiologist. On Zollschan see: Hart, Mitchell B. Social science and the politics of modern Jewish Identity. Palo Alto: Stanford University Press; 2000. 
rates of favus and ringworm among children. To mention just few numbers: In Lithuania in 1922 21\% of the Jewish children were infected with ringworm ${ }^{57}$. In Bessarabia 10,000 children with ringworm were counted ${ }^{58}$. The campaign against favus and ringworm had an enormous logistic aspect and was probably the biggest campaign against these ailments. Tens of Thousands of children were treated and healed by $x$-rays. Healing Jews from favus and ringworm, loathsome diseases that were highly stigmatized as related to poverty and backwardness had an important symbolic meaning. OZE considered this campaign as a major success; it had a prominent presence in its all early publication and served as a yardstick for future public health campaigns.

\section{Discussion}

In the interwar period, OZE established an impressive public health network. OZE succeeded to incorporate already existing communal Jewish philanthropic organizations as well as few modern Jewish medical institutions. Yet, OZE rational was very different from previous local Jewish approaches. It sought to create a comprehensive Jewish welfare system with the goal of promoting the study and knowledge of medical and sanitary practices, detecting and curing diseases among Jews, preventing epidemics, focusing mainly on creating living conditions conducive to the normal physical and mental development of Jewish children. OZE was aware of its broad social implication for Jewish life and the political power of medicine and public health. Yet OZE activities should be understood in the broader context of interwar transnational health and relief operations. Other minorities, such as Poles or Armenians, suffered from persecution and dire physical conditions. Relief to such groups was based on both local and international forces, serving as an important catalyst for ethno-national identity formation. In the case of OZE, the resources gathered - monetary, scientific, managerial and political- although not sufficient, were quite impressive.

OZE served as an intermediary between the local context -Eastern European Jewish life, as expressed both in health and non-health related

57. Die Entstehung, n. 36, p. 12.

58. Die Entstehung, n. 36, p. 14. 
fields, its institutions and culture- and the reform ideals coming from abroad, mainly from Western Europe and the US. The Jewish body, both individual and collective, was perceived as sick and in a need for cure. The cure was to be brought by a public health campaign of better education, better living condition, but also with the help of «modern» science and technology. Jews needed to learn how to wash and eat but their bodies needed to be screened for various diseases and treated accordingly. A measure such as mass irradiation against favus and ringworm was just one example of an unprecedented public health campaign against a stigmatized illness that has also important consequences for future immigrants. OZE, in contrast to foreign relief organizations had the «know-how» in order to implement such measures. The knowledge and money could be American or Western European, but they could not be implemented, both in the Jewish communities and in their interaction with the local governments, without the situated knowledge of organizations such OZE.

The paper also aimed to show how public health work among Eastern-European Jewish communities became a platform for transnational collaboration, in this case between the JDC and OZE and how OZE, as a local organization with broader support -scientific, organizational and political, turned to become a crucial Jewish body in the field of preventive medicine and social medicine among Eastern European Jewry up until the Holocaust. In addition the presented case shows the centrality of health as an important leverage for promoting Jewish political rights as a minority. This case study can serve as a starting point to other needed studies of other minorities' health and relief activities in the interwar period in Europe.

There are still many questions that should be further investigated in the history of OZE: How did OZE succeed to mobilize medical knowledge and resources in the context of interwar Eastern Europe? How did they interact with the local players, Jewish and non-Jewish, and players from abroad? And probably the most interesting question: Why, considering OZE successes, its memory was almost totally erased from the collective consciousness, as expressed in the history of medicine and more important in Jewish history literature? Part of the answer rests probably in the broader context of the general memory loss of interwar Eastern European Jewish history related to the rise of Zionism, the holocaust and the establishment of Israel. Yet, as this article presented, interwar Jewish health in general and OZE history in particular can serve as a rich case study for a better understanding of the interplay between health, race politics, culture and identity. 